\title{
Education and the empowerment of women in household decision-making in Spain
}

\begin{abstract}
We analyze whether investment in the education of both women and men serves to empower wives resulting in more balanced household decisions being taken on matters related to consumption and financial management. We consider that household decision-making can be made by mainly the wife, mainly the husband or the couple acting jointly. We then apply multinomial probit models to the Spanish Living Conditions Survey of 2010. Results show that, when controlling for demographic, family and labor market characteristics, the level of education of both the husband and wife has a positive effect in terms of a more egalitarian decision-making process in relation to three areas of expenditure: daily shopping, expensive purchases of consumer durables, and significant expenditure on children. However, only women's education has a positive effect on borrowing money and no effect of education is observed with regard to the use of savings. Results are less conclusive for households where decisions are taken primarily by the wife or husband, since men's education increases the role of husbands in the household making-decision process whereas no effect of wives' education is observed.
\end{abstract}

Keywords: Consumption; Education; Empowerment; Household; Multinomial; Savings. 


\section{Education and the empowerment of women in household decision-making in Spain}

Introduction

Important economic decisions are often made by households rather than by individuals. Just who is in charge of such major household decisions was the object of a pioneering analysis by Blood and Wolfe (1960). There are several models of household behavior that explain the decisions taken by its members. The traditional neoclassical model, known as the 'unitary' model, which is based on the existence of an altruistic husband, assumes that households behave as if they were a single entity with a common utility function and income pooling (Becker, 1991). An alternative or 'collective' model, however, considers that household members have different preferences and, as a result, household behavior is determined in a bargaining process that leads to an efficient use of the available resources (Vermeulen, 2002; Browning et al., 2006; Himmelweit et al., 2013). Also, several models have sought to relate this bargaining power with access to economic resources outside the household (Usdansky and Parker, 2011).

Although collective models allow for the participation of both spouses in the decision-making process within households, women are traditionally less involved at all levels (Jan and Akhtar, 2008), even allowing for the dramatic changes in family and social relationships in the second half of the 20th century characterized by a trend towards greater equality in most dimensions of the roles of men and women (Thornton and Young-DeMarco, 2001). In this context, it seems pertinent to analyze the role of education in household decision-making. It is relevant to determine whether education serves to empower women in their marital 
negotiations and, thus, to achieve a more balanced decision-making process in relation to household economic activities. We do not consider the role of other family members, such as children, who can be involved in the household decision-making process (see Wut and Chou, 2013).

This impact of education falls within the analytical framework of Human Capital Theory, typically referred to as the 'non-monetary benefits of education', which include, among others, the positive effects of education on health, fertility or family structure (see Vila (2000) and Wolfe and Haveman (2001) as well as Escardíbul (2005) for Spain). Education is a key instrument in empowering women in the household because it helps them gain a better understanding of their rights and responsibilities, and it can raise their confidence with regard to their possibilities, especially in less developed countries (Acharya, 2008). Mederer (1993) shows that women with more resources demand a more equal division of labor and perceive anything less than that as unfair. Similarly, Usdansky and Parker (2011) show that married women in the US with a college degree express greater gender egalitarianism.

This paper focuses on the impact of the education of both genders on a woman's participation in specific aspects of household decision-making, such as consumption decisions (daily shopping, expensive purchases of consumer durables and significant expenditure on children) and borrowing and saving decisions. Thus, the purpose of the research is to analyze the role of education in the household decision-making process. Our study makes several contributions to the literature. First, rather than examining solely the effect of women's education on their empowerment in the household decision-making process, we also consider the impact of men's education. Second, to date, most studies conducted in this field have adopted a qualitative approach, but by undertaking a quantitative analysis we are able to 
include a large sample of households. Finally, this is the first empirical analysis to be carried out in Spain, a Mediterranean economy with strong cultural links to other Southern European countries. As such, this study should serve as a useful guide for the conducting of analyses in these similar countries. In comparison to Northern European countries, Southern European countries have a limited development of family policies, and public welfare policies are characterized by family solidarity and dependency still based on the existence of a male breadwinner, especially in Italy, Greece and Spain (Flaquer, 2002; Naldini, 2003; Moreno Mínguez, 2013). Likewise, Southern European countries are also more attached to traditional gender roles in the division of labor in the household (Hank and Jürges, 2007). We expect that in a country like Spain, where equality between men and women has advanced significantly since the advent of democracy (Zufiaurre et al., 2010), an increase in the educational level of the wife and/or husband is associated with a more egalitarian distribution of household decisions.

\section{Literature review}

In this section we examine studies that consider the role of education in household decisionmaking. We focus on expenditure decisions but we also consider the division of household labor (a topic mainly analyzed in more developed countries). Most of the literature considering the impact of education on women's autonomy focuses on developing countries and examines a range of different aspects related to the household. These studies show that women with a higher level of education make more household decisions regarding consumption and savings than those with lower levels. Likewise, the higher the education level of their husbands, the more egalitarian these household decisions tend to be. 
In Asia, Sai Sujatha and Brahmananda Reddy (2009) associated women's education in Andhra Pradesh (India) with greater autonomy in their decision-making concerning major household purchases as well as those for daily household chores. Moreover, women's access to money and their freedom to decide how to spend it (that is, having and using a bank or savings account) were also positively related to the level of education attained. Likewise, Chanda et al. (2012) concluded that in Bangladesh, women's say in decisions regarding household purchases increased with education. In the case of Taiwan, Xu and Lai (2002) showed the positive effects of a wife's education on the likelihood of her making decisions alone or jointly (with her husband) on consumption and estate purchases. Finally, in the framework of experiments examining theories of risky choice among households as opposed to individuals, Carlsson et al. (2013) analyzed household decision-making in a high-stakes experiment in China, whereby spouses had to choose between risky lotteries (first separately and then jointly). Their analysis showed that although a couple's joint decision was typically similar to the husband's, women with more education than their husbands had a stronger influence on the joint decision.

In Latin America, Lawrence and Mancini (2008) found that increases in male education and female labor force participation (which is clearly related to women's educational level) in Venezuela raised the probability that couples made decisions equally regarding consumption and savings, among other issues. In Mexico, Oropesa (1997) reported that educational attainment was a key variable for increasing the likelihood of wives having an equal say in decisions and their degree of satisfaction with their influence in household decisions.

In the case of more developed countries, studies have tended to focus more closely on the role of education in the division of household labor (see Gupta, 2006; Ruppanner, 2010). One 
notable exception is the work of Treas and Tai (2012). With representative samples from 31 countries (data were drawn from the 2002 International Social Survey Program) in Europe (including Spain), Latin America, Israel, Japan, Australia, New Zealand, the United States, and Russia, the authors focused on heterosexual couples (aged 18 to 65, married with children younger than 18 years in the household). They concluded that, in relation to major purchases, better educated wives were more likely to make decisions jointly with their husbands.

These results are in line with Coltrane (2000), who reviewed more than 200 studies of household labor, and concluded that higher levels of education disposed individuals to a more equal allocation of household chores. In addition, Hank and Jürges (2007) showed that male and female education increased the egalitarian division of household labor across Europe. Nevertheless, Southern European countries have subscribed to more traditional gender roles in household management (Nordenmark, 2004; Hank and Jürges, 2007; Strickney and Konrad, 2007). Thus, although differences among countries still exist education helps to achieve higher egalitarian levels with regard to household labor.

Finally, in her review of various studies, Pahl (2000) showed that the greater the proportion of household income provided by the wife, the more likely she is to control household finances and to have power in financial decision-making. Although Pahl did not specifically consider education, a positive effect of education can be assumed given its relationship with earnings.

With regard to income, most studies suggest that women's earnings do not bring an automatic increase in their bargaining power in the household, since gender ideologies may be more 
important than income in some cases (Tichenor, 1999; Grasmuck and Espinal, 2000; Zipp et $a l ., 2004)$. Thus, it is not women's income per se that is important but the extent to which higher levels of income allow women to see themselves differently (Bruce, 1989). In addition, the income provider may condition the type of spending of the household. Thus, Shelley et al. (1998), Pahl (2000), and Vogler et al. (2008) show that expenditures on child care or for the whole household increase with women's incomes. For less developed countries, Anderson and Eswaran (2009) show that in Bangladesh earned income could be more important than unearned income in empowering women: it is not employment as such but employment outside their husbands' farms that contributes to women's autonomy. To sum up, education seems to have a greater effect on increasing the role of women in household decision-making than income.

\section{Method}

\section{Data and sample}

This study draws on the secondary module entitled "Ability to make decisions" of Spain's Living Conditions Survey (LCS) for 2010. The LCS was conducted by the National Statistics Institute in collaboration with Eurostat within the broader framework of European Union Statistics on Income and Living Conditions (EU-SILC). The LCS is an annual survey with a sample size of about 16,000 households, distributed in 2,000 census sections.

Questions regarding a couple's decision-making on family issues were asked of each current household member aged 16 and over living with a partner. Data allow us to distinguish 
between married and not married couples. However, since most couples are married (more than $90 \%$ in cohorts before 1970 and $82 \%$ after 1970), in the analysis we do not make such a distinction. Hereinafter we refer to the individuals as husband and wife regardless of the legal status of their union. The survey also includes both heterosexual and homosexual couples. However, we did not have sufficient observations to analyze the decision-making in homosexual couples $(0.6 \%)$, and so we only considered heterosexual unions.

We matched each respondent with his or her partner for a total of 9,480 couples in the whole household survey; yet, the match was not complete, as less than 3 percent of individuals (both men and women) failed to respond to any of the questions that were relevant for this study. The statistical analysis was performed with a sample where full information was provided for all the variables used. No significant differences were observed between the descriptive statistics of the variables used in the regression analysis and those from the whole sample. Information is collected through in person interviews (and supplemented with phone interviews) with the members of each of the households under study. The time period of data collection is around three months during the first half of the year. Data are nationally representative (see National Statistics Institute ECS, 2005).

\section{Variables}

We analyze the couples' decision-making process in relation to five aspects of the household economy. The first three are consumption decisions: daily shopping, expensive purchases of consumer durables or furniture, and significant expenditure incurred in relation to children (up to 16 years old). Significant expenditure is self-defined by the person interviewed (although some hints may be provided to help the interviewees to answer). The last two are 
decisions related to borrowing and saving. All the questions enquiring about the decisionmaking process in relation to these aspects of the household economy are phrased as follows: "The following questions about making certain decisions relate to you and your partner. Who makes decision about...?" The interviewees can respond in one of three ways: (a) More me (b) Balanced (c) More my partner. For each one of the five questions a different sample has been selected, including individuals who answered (a), (b) or (c) to each question and excluding individuals who answered another possible response such as (d) Neither of us has had to make such decisions or (e) We have no savings in common (for the question on savings). The question related to significant expenditure on children was asked only of respondents who had children up to 16 years old. On the basis of the responses to these questions we study couples' decision-making in consumption as well as in borrowing and saving. We have five dependent variables, each of which comprises three discrete categories: (a) mainly the husband makes decisions, (b) mainly the wife makes decisions, and (c) the husband and wife make joint decisions.

Table 1 shows the distribution of our five dependent variables. The percentages in the first column correspond to the pooled responses, whereas the percentages in the second and third columns correspond to the answers given by the male and female members of the couples, respectively. We find only minor differences between the distribution of male and female responses in each couple to questions regarding their decision-making (less than two percentage points). This suggests that in each couple the husband and wife are in substantial agreement with regards to how decisions about the household economy are made. For this reason, unlike Hank and Jürges (2007), this study does not undertake a separate analysis by gender. 
As shown in Table 1, the percentage of couples in which both members make joint decisions is lower for consumption issues than for borrowing and saving ones. This is particularly the case in daily shopping, where only $33 \%$ of respondents report making joint decisions, whereas $62 \%$ of respondents declare that mainly women decide. Thus, this task in Spain is predominantly decided by women as is commonly reported (see Bianchi et al., 2000, and Coltrane, 2000). The decisions on expensive purchases of consumer durables and significant expenditures on children are made primary by wives and husbands together $(83 \%$ and $78 \%$ respectively). Men hardly make decisions alone in these issues (only 3\% on major purchases and $1 \%$ on expenditure on children), whereas the percentages of decisions mainly taken by women are higher (14\% and $20 \%$ respectively). A different pattern is observed in household decisions on loans and savings. Only $10 \%$ of these decisions are made by either wife or husband alone (being quite evenly distributed), whereas $90 \%$ of respondents report making joint decisions in these areas.

(Insert Table 1 around here)

With regards to independent variables, we consider both human capital and other control variables. Human capital is measured in terms of both the husband's and wife's educational attainment following the International Standard Classification of Education (ISCED-1997). Thus, we consider individuals with at least primary education, lower secondary education (compulsory education ends at the age of 16 in Spain), upper secondary education (academic or vocational), and tertiary education (which includes post-secondary education, mainly university studies). 
The control variables are related to the labor market, on the one hand, and demographic and family characteristics, on the other. Both types of variables are also related to power in decision-making (see Usdansky and Parker (2011) for the labor market and Hamel (1990) and Clark et al. (1991) for demographic and family characteristics). Labor market variables are whether the husband or wife has a paying job and, if so, their net monthly wage (the variable is coded 0 if individuals are not employed). Demographic and family characteristics are the following: the birth cohort of the husband and the wife, the country of birth (Spain or another country) of both members of the couple, whether they are living in a family with children under the age of 16 , the population density of the household residence (high, medium, and low), and the region of residence (there are 17 regions in Spain and 2 autonomous cities). For more details see the National Statistics Institute ECS, 2005 and the descriptive statistics for these independent variables in the Appendix (Table A). It should be noted that the birth cohort variable reflects cultural or sociopolitical factors linked to the generation of the people included in the analysis. Thus, the sociopolitical turning points in the modern history of Spain are considered through three birth cohorts: individuals who have lived their childhood under a dictatorship (before 1959, as reference category); in the transition to democracy period (the 1960s); and during the pre-democracy and democracy periods (the 1970s and after). The analysis is similar to that of Xu and Lai (2004) for Taiwan.

\section{The empirical strategy}

The empirical strategy adopted here comprises a multinomial probit regression of the probability that mainly the husband, mainly the wife or the two jointly make the economic decisions in their respective households. The baseline category in all estimations is that mainly the husband makes the economic decisions in the household, and this option is 
compared to mainly the wife making decisions and to both spouses making joint decisions. The reason why we opt to use the multinomial probit rather than the commonly used multinomial logit is that the latter requires the assumption of independence of irrelevant alternatives, whereas the multinomial probit relaxes that assumption. The assumption of independence of irrelevant alternatives means that when an individual faces a question in which they have to choose from the possible option, the probability that they choose one option is independent of the rest of alternatives (either if they are explicitly on the questionnaire or if they are not). In our analysis we cannot be sure that this assumption is validated since the number of existing options is relevant when someone is asked about how household decisions related to consumption or savings are taken. Thus, following Greene (2012), to be sure that our estimates are correct, we use a multinomial probit model that relaxes the assumption of independence of irrelevant alternatives.

The advantage of the multinomial logit is that the coefficients can be directly interpreted as odds ratios (Long, 1997). Nevertheless, the calculation of marginal effects from the probit estimates is straightforward, and these are generally easier to interpret and understand than the odds ratios. The marginal effects from the probit estimates are calculated using the STATA 13 program, which provides robust estimators of the variance (Long \& Freese, 2006; Solon et al., 2015).

The structure of the multinomial probit equation is shown in (1), where $j=1,2$ and 3 refers to the different values of the dependent variable (the three possible outcomes for the economic decision). The term in the log-likelihood that corresponds to the choice of alternative $\mathrm{q}$ is shown in equation (2), and the probability for this occurrence in (3). The J-1 other choices are a cumulative probability from a $(J-1)$-multivariate normal distribution. 
$U_{j}=x^{\prime}{ }_{j} \beta_{j}+\varepsilon_{j}, \quad j=1, \ldots, J, \quad\left[\varepsilon_{1}, \varepsilon_{2}, \ldots, \varepsilon_{J}\right] \sim N[0, \Sigma]$

$\operatorname{Pr}\left[\right.$ choice $\left._{q}\right]=\operatorname{Pr} o b\left[U_{q}>U_{j}, j=1, \ldots, J, j \neq q\right]$

$\operatorname{Pr}[$ choice $q]=\operatorname{Pr}\left[\varepsilon_{1}-\varepsilon_{q}>\left(x_{q}-w_{1}\right)^{\prime} \beta, \ldots, \varepsilon_{J}-\varepsilon_{q}>\left(x_{q}-x_{J}\right)^{\prime} \beta\right]$

In the above expressions, $X$ refers to the vector of explanatory variables, $\beta$ is the vector of coefficients linked to the explanatory variables, and $\varepsilon$ are the stochastic error terms, which are assumed to have independent, standard normal distributions. In the regression analysis data is not weighted since the Living Conditions Survey follows a complex sampling method, based on multistage and stratification, and no information about the weights for the strata is provided. In addition, we have tested the multicollinearity using the variance inflation factor (VIF) indicator as if our model was a lineal one. The VIF in all independent variables had a value between 1.2 and 6.7. Thus, being all values under 10, we did not have a problem of multicollinearity in our regressions.

\section{Results}

The two outcomes of the multinomial probit regression models are shown separately in Tables 2 and 3. Table 2 shows regression results of the probability that both wife and husband take part in household decisions instead of mainly the husband. Table 3 displays the results of the probability that mainly wives make decisions compared to mainly husbands deciding. We show the marginal effects of wife's and husband's education as well as the effect of income (men's and women's wages). All the estimations include the common set of control variables related to labor market, demographic and family characteristics. 
Results in Table 2 show that achieving higher levels of education by both wives and husbands increases the probability that household consumption decisions (such as daily and major household needs as well as decisions on significant expenditure on children) are made together. That is, education is statistically significant when tertiary education (and even upper secondary in some cases) is achieved. However, education hardly affects borrowing and saving decisions of the households: only wife's education has a positive bearing on spouses deciding together with regards to loans, whereas no effect of education for either spouse is observed for savings.

Thus, wife's education fosters a more egalitarian decision-making process in all areas analyzed except savings, whereas husband's education fosters it on all issues considered except loans and savings. Therefore, it seems that education of men and women, especially tertiary education, is relevant to fostering an egalitarian view in the household in consumption decisions. However, education seems less relevant in fostering egalitarianism with respect to loans and savings, especially in the case of husband's education.

Table 3 shows that higher levels of husband's education (having achieved tertiary education and even upper secondary in most cases) reduces the probability that wives mainly decide compared to husbands mainly deciding. However, wife's education hardly has an effect on these probabilities. Therefore, demographic and family characteristics being equal, if the husband is better educated then the wife is less likely to decide alone.

(Insert Table 2 and 3 around here) 
With regards to income, as shown in Table 2, husband's salary increases the probability that joint decisions are taken within the family compared to mainly the husband deciding (wife's salary is hardly significant). Likewise, results in table 3 show that as the salary of the husband increases the likelihood that mainly the wife decides compared to mainly the husband deciding is reduced. In this analysis the wife's salary is also hardly significant. The effects of other variables are not shown for the sake of brevity but results are available upon request.

\section{Discussion}

We can conclude that increased educational attainment of both men and women serves to empower wives in terms of their making more joint decisions in at least three of the five areas of the household economy analyzed: daily shopping, expensive purchases of consumer durables and significant expenditure on children. In addition, women's education also increases the probability of an egalitarian decision-making process in borrowing money. Our results are consistent with evidence from analyses of the non-monetary benefits of education as well as with the literature on the impact of improved education on egalitarianism (see Wolfe and Haveman, 2001; Usdansky and Parker, 2011). The positive effect of education on joint-decision in the household is a relevant issue for countries such as Spain, a Southern European country that has maintained more traditional gender roles in questions of household management (Nordenmark, 2004; Strickney and Konrad, 2007).

However, results show the limited impact of education on fostering a joint decision process in economic issues within the household. On the one hand, education positively affects consumption decisions but hardly affects borrowing and saving decisions. On the other hand, 
the effect of education is basically confined to having attained higher education. Other levels such as upper secondary education are hardly significant.

Results are less clear for households where mainly one of the spouses makes the decisions. In these cases, husband's education reduces the probability of the wife deciding alone, whereas wife's education has no effect. These results may mean that husband's education reduces wife's empowerment in the household decision-making process. However, from the perspective of the division of household labor (see Coltrane, 2000 and Hank and Jürges, 2007), we also think that maybe these results show a reduction of housework for women, since their more educated husbands are taking decisions alone about daily shopping, expenditure on children or main household purchases, three activities in which men have been much less involved (see Table 1). This does not seem so clear in the case of borrowing and saving decisions, where decision-making is distributed more equally between men and women when they are the ones who mainly decide within the household. Thus, the results seem to show that education fosters a more equal distribution of household tasks related to consumption (where husbands are less involved).

To sum up, our results suggest that gender equality policies need to take into consideration the role of education of both men and women in their attempts to foster egalitarianism since education increases joint decision-making in consumption decisions. In this case, education increases the probability that household decisions are made together by the couple or that husbands get involved when the decision is traditionally made by the wife. However, results are not so clear in borrowing and saving decisions. 
We believe that joint decision-making is a benefit for both couples and the society as a whole. Thus, our results may imply that the benefits of education are higher than those reported when only the economic returns of education are computed, since this type of nonmonetary benefit should also be taken into consideration.

Nevertheless, education alone will not foster an egalitarian system of household decisionmaking. Thus, other public policies are suggested, although more research is needed. Firstly, governments should implement family policies that may improve women's participation in the labor market, as well as egalitarian policies to reduce the gap between men's and women's working conditions. Better working conditions for women may increase their power in the labor market and the society as a whole and, therefore, foster a more egalitarian joint decision process at home. The Spanish labor market has changed a lot in recent decades and is partially moving from a traditional male-breadwinner model to a dual-breadwinner one (Lewis, 2001; Dema-Moreno, 2009). Likewise, women's rate of labor activity has increased significantly (from $27.1 \%$ in 1980 to $53.8 \%$ in 2015 ). However, there is still a high gender gap in wages (around 20\%), unemployment (22.5\% for women versus 19.5 for men) and part-time contracts $(25.1 \%$ for women and $8.0 \%$ for men). Thus, Spain (as well as Italy and Greece) is below most countries of the European Union with regards to women's labor market conditions (OECD, 2008; Guner et al., 2012; Wall and Escobedo, 2013; Guner et al., 2014).

Secondly, education policies aimed at modifying gender norms should be implemented. In primary and secondary schools, children should have the opportunity of discussing gender roles, whereas in tertiary education, courses dealing with subjects that examine gender and patriarchal relations should be introduced (Carrasco and Dominguez, 2011). In this sense, it 
has to be taken into consideration that consumption and borrowing and saving decisions that may seem to be as a result of negotiation between spouses are not always the case but rather tend to follow established customs (see Dema-Moreno, 2009 for a qualitative analysis for Spain).

Our investigation does not provide an explicit analysis of the decision-making model itself. However, our results seem to be more consistent with a 'collective' model (described in the introduction) rather than with a 'unitary' model, since education encourages joint decisionmaking. This is a characteristic of the 'collective' model, which considers that household members have different preferences and, therefore, household behavior is determined through a bargaining process. Thus, education of both men and women helps wives to actively participate in the household decision-making process on consumption.

Our study has several limitations that should guide future research. Firstly, the quantitative analysis should be complemented with qualitative research that helps to understand the reasons behind the actions of husbands and wives with regards to household decisionmaking. Secondly, other types of couples should be analyzed, such as homosexual couples as well as the different ways couples may live together (first marriage, second and other marriages, not married couples, etc.), since the development of different family models, especially in Western societies, questions the focus on traditional families only (see some examples in Domínguez-Folgueras, 2012; Goldberg et al., 2012; Schneider et al., 2013).

However, we want to highlight the relevance of the analysis presented here for several reasons. Firstly, our study considers not only the effect of women's education on their empowerment in the household decision-making process, but also the impact of men's 
education. Our results show that both types of variables are relevant in order to explain the decision-making process within the household. Secondly, we show that the effect of education changes if the husband or the wife mainly takes the decision or whether they decide together is examined. Thirdly, our analysis considers a large number of households. Finally, our research is developed in a country where no previous evidence on the effect of education on household decision-making related to expenditure existed, and that may be useful for other analyses developed in the Mediterranean area. 


\section{References}

Acharya, Y. (2008) Women's education and intra-household autonomy: Evidence from Nepal. Journal of Development and Social Transformation, 5, 5-12.

Anderson, S. \& Eswaran, M. (2009) What determines female autonomy? Evidence from Bangladesh. Journal of Development Economics, 90, 179-191.

Becker, G. (1991) A treatise on the family: Enlarged edition. Harvard University Press, Cambridge, MA.

Bianchi, S. M., Milkie, M. A., Sayer, L. C. \& Robinson, J. P. (2000) Is anyone doing the housework? Trends in the gender division of household labor. Social Forces, 79, 191-228.

Blood, R. O. \& Wolfe, D. (1960) Husbands and wives. Free Press, New York.

Browning, M., Chiappori, P. A. \& Lechene, V. (2006) Collective and unitary models: A clarification. Review of Economics of the Household, 4, 5-14.

Bruce, J. (1989) Homes divided. World Development, 17, 979-991.

Carlsson F., Martinsson P., Qin P. \& Sutter M. (2013) The influence of spouses on household decision making under risk: An experiment in rural China. Experimental Economics, 16, 383-401. 
Carrasco, C. \& Domínguez, M. (2011) Family strategies for meeting care and domestic work needs: Evidence from Spain. Feminist Economics, 17, 159-188.

Chanda, S. K., Howlader, H. \& Nahar, N. (2012) Educational status of the married women and their participation at household decision making in Rural Bangladesh. International Journal of Advancements in Research and Technology, 1, 137-146.

Clark, R., Ramsbey, T. W. \& Adler, E. S. (1991). Culture, gender, and labor force participation: A cross national study. Gender and Society, 5, 47-66

Coltrane, S. (2000) Research on household labor: Modeling and measuring the social embeddedness of routine family work. Journal of Marriage and Family, 62, 1208-1233.

Dema-Moreno, S. (2009) Behind the negotiations: Financial decision-making processes in Spanish dual-income couples. Feminist Economics, 15, 27-56.

Domínguez-Folgueras, M. (2012). Is cohabitation more egalitarian? The Division of household labor in five European countries. Journal of Family Issues, 34, 1623-1646.

Escardíbul, J.O. (2005) The non-monetary effects of education on smoking and quitting smoking in Spain. European Journal of Education, 40, 45-58.

Flaquer, L. (2002) Political intervention and family policy in Europe \& the USA: Family policy \& the maintenance of the traditional family in Spain. In: Carling, A., Duncan, S. 
\& Edwars, R. (Eds.), Analysing families: Morality and rationality in policy and practice. London: Routledge, 84-92.

Goldberg, A. E., Smith, J. Z. \& Perry-Jenkins, M. (2012) The division of labor in lesbian, gay, and heterosexual new adoptive parents. Journal of Marriage and Family, 74, 812828.

Grasmuck, S. \& Espinal, R. (2000) Market success or female autonomy? Income, ideology and empowerment among micro entrepreneurs in the Dominican Republic. Gender and Society, 14, 231-255.

Greene, W. H. (2012) Econometric Analysis. Prentice Hall, Boston.

Guner, N., Kaya, E. \& Sánchez-Marcos, V. (2014) Gender gaps in Spain: policies and outcomes over the last three decades. SERIEs, Spanish Economic Association, 5, 61-103.

Gupta, S. (2006) Her money, her time: Women's earnings and their housework hours. Social Science Research, 35, 975-999.

Hank, K. \& Jürges, H. (2007) Gender and the division of household labor in older couples. A European perspective. Journal of Family Issues, 28, 399-421.

Himmelweit, S., Santos, C., Sevilla, A., \& Sofer, C. (2013). Sharing of resources within the family and the economics of household decision making. Journal of Marriage and Family, 75, 625-639 
Jan, M. \& Akhtar, S. (2008) An analysis of decision making power among married and unmarried women. International Journal for Studies on Home and Community Science, 2, 43-50.

Lawrence, P., \& Mancini, M. (2008) Household decision-making: A case study in Venezuela. Revista de Economía Institucional, 10, 213-239.

Lewis, J. (2001) The Decline of the Male Breadwinner Model: Implications for Work and Care. Social Politics 8, 152-69.

Long, J. S. (1997) Regression Models for Categorical and Limited Dependent Variables. SAGE.

Long, J. S. \& Freese, J. (2006). Regression Models for Categorical Dependent Variables Using Stata. StataCorp LP, College Station, Tex.

Mederer, H. J. (1993) Division of labor in two-earner homes: Task accomplishment versus household management as critical variables in perceptions about family work. Journal of Marriage and Family, 55, 133-145.

Moreno Mínguez, A. (2013) Working parents, family and gender in Spain from an European comparative perspective. In: Moreno Mínguez, A. (Ed.), Family well-Being. European perspectives, New York: Springer, 177-201.

Naldini, M. (2003). The Family in the Mediterranean Welfare States. London, Frank Cass. 
National Statistics Institute ECS. (2005) Living Conditions Survey. Methodology. [WWW document]. URL

http://www.ine.es/en/daco/daco42/condivi/ecv_metodo_en.pdf\#page=2\&zoom=auto, 0,745 (accessed on March 2nd, 2014).

Nordenmark, M. (2004) Does gender ideology explain differences between countries regarding the involvement of women and men in paid and unpaid work? International Journal of Social Welfare, 13, 233-243.

OECD (2008) The price of prejudice: labour market discrimination on the grounds of gender and ethnicity. In: OECD Employment Outlook 2008, Chapter 3. OECD Publishing, Paris.

Oropesa, R. S. (1997) Development and marital power in Mexico. Social Forces, 75, 12911317.

Pahl, J. (1989) Money \& Marriage. Macmillan, Basingstoke.

Pahl, J. (2000) Couples and their money: patterns of accounting and accountability in the domestic economy. Accounting, Auditing \& Accountability Journal, 13, 502-517.

Ruppanner, L. E. (2010) Cross-national reports of housework: An investigation of the gender empowerment measure. Social Science Research, 39, 963-975.

Sai Sujatha, D. \& Brahmananda Reddy, G. (2009) Women's education, autonomy and fertility behaviour. Asia-Pacific Journal of Social Sciences, I, 35-50. 
Schneider, H., Schönenberg, I., \& Ferié, F. (2013). The distribution of influence in purchase decisions by male homosexual couples. Journal of Consumer Behaviour, 12, 345-357.

Shelley, A. P. \& Burton, P. S. (1998) What's Mine is Yours? The Influence of Male and Female Incomes on Patterns of Household Expenditure. Economica, 65, 599-613.

Solon, S., Haider, S. J. \& Wooldridge, J. (2015). What Are We Weighting For? Journal of Human Resources, 50, 301-316.

Strickney, L. T. \& Konrad, A. M. (2007) Gender-role attitudes and earnings: A multinational study of married men and women. Sex Roles, 57, 801-811.

Thornton, A. \& Young-DeMarco, L. (2001) Four decades of trends in attitudes toward family issues in the United States: The 1960s through the 1990s. Journal of Marriage and Family, 63, 1009-1037.

Tichenor, V. (1999) Status and income as gendered resources: the case of marital power. Journal of Marriage and the Family, 61, 638-50.

Treas, J. \& Tai, T. (2012) How couples manage the household: Work and power in crossnational perspective. Journal of Family Issues, 33, 1088-1116.

Usdansky, M. L. \& Parker, W. M. (2011) How money matters: College, motherhood, earnings, and wives' housework. Journal of Family Issues. 32, 1449-1473. 
Vermeulen, F. (2002). Collective household models: principles and main results. Journal of Economic Surveys, 16, 533-564.

Vila, L. E. (2000) The non-monetary benefits of education. European Journal of Education, 35, 21-32.

Vogler, C., Lyonette, C. \& Wiggins, R. D. (2008) Money, power and spending decisions in intimate relationships. The Sociological Review, 56, 117-143.

Wolfe, B. L. \& Haveman, R. (2001) Accounting for the social and non-market benefits of education. In: The contribution of human and social capital to sustained economic growth and well-being (ed. by J. Helliwell), pp. 221-250. OECD, Paris.

Wall, K. \& Escobedo, A. (2013) Parental leave policies, gender equity and family well-being in Europe: A comparative perspective. In: Moreno Mínguez, A. (Ed.), Family WellBeing, 103-129.

Wut, T. M. \& Chou, T. J. (2013) Do family members agree on family purchase decision? An empirical study among families in Hong Kong. International Journal of Consumer Studies, 37, 344-350.

Xu, X. \& Lai, S. (2002) Resources, gender ideologies, and marital power: The case of Taiwan. Journal of Family Issues, 23, 209-245.

Xu, X. \& Lai, S. (2004) Gender Ideologies, Marital Roles, and Marital Quality in Taiwan. Journal of Family Issues, 25, 318-355. 
Zipp, J. F., Prohaska, A., and Bemiller, M. (2004) "Wives, Husbands, and Hidden Power in Marriage”, Journal of Family Issues, 25, 923-948.

Zufiaurre, B., Pellejero, L. \& Weiner, G. (2010) Gender equality and education in Spain: ideology and governance. Education Inquiry, 1, 399-414. 
Table 1. Descriptive Statistics: Household decision measure

\begin{tabular}{|c|c|c|c|}
\hline Household decision & $\begin{array}{c}\text { All } \\
\text { (Percent) }\end{array}$ & $\begin{array}{c}\text { Men } \\
\text { (Percent) }\end{array}$ & $\begin{array}{c}\text { Women } \\
\text { (Percent) }\end{array}$ \\
\hline \multicolumn{4}{|l|}{ Daily household needs } \\
\hline Husband & 5.25 & 5.84 & 4.66 \\
\hline Wife & 61.74 & 60.88 & 62.60 \\
\hline Both & 33.01 & 33.29 & 32.74 \\
\hline \multicolumn{4}{|l|}{ Major household purchases } \\
\hline Husband & 2.67 & 2.77 & 2.56 \\
\hline Wife & 14.23 & 14.33 & 14.14 \\
\hline Both & 83.10 & 82.91 & 83.29 \\
\hline \multicolumn{4}{|c|}{ Significant expenditure on children } \\
\hline Husband & 1.16 & 1.44 & 0.88 \\
\hline Wife & 20.46 & 19.92 & 21.01 \\
\hline Both & 78.38 & 78.64 & 78.11 \\
\hline \multicolumn{4}{|l|}{ Loans } \\
\hline Husband & 5.12 & 5.17 & 5.07 \\
\hline Wife & 4.46 & 4.40 & 4.52 \\
\hline Both & 90.42 & 90.44 & 90.41 \\
\hline Savings & 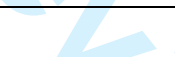 & & \\
\hline Husband & 4.23 & 4.63 & 3.84 \\
\hline Wife & 6.65 & 6.38 & 6.92 \\
\hline Both & 89.12 & 88.99 & 89.24 \\
\hline
\end{tabular}


Table 2. Multinomial Probit Regression (Joint decision compared to mainly the husband): Marginal Effects

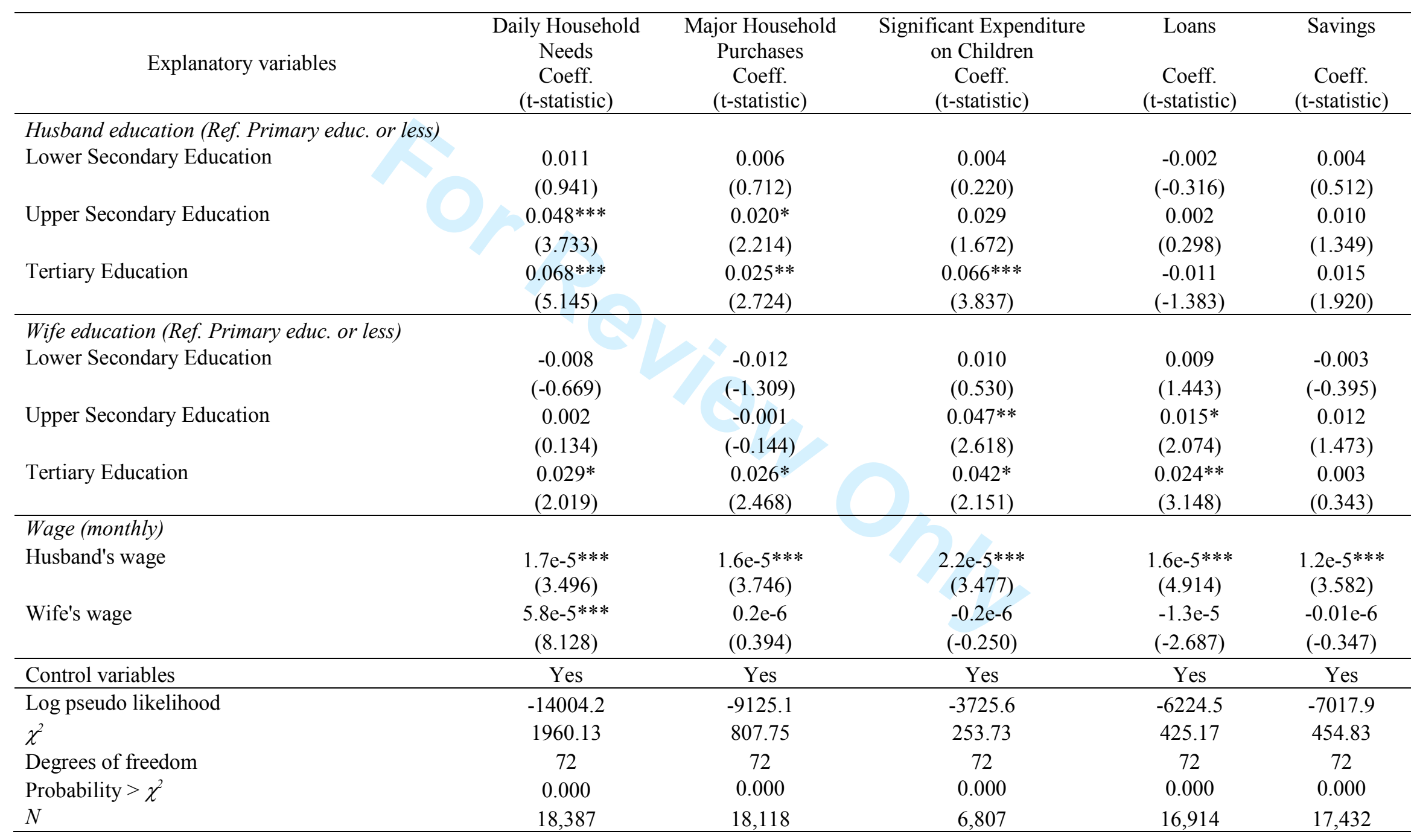


Note: Control variables included are the following: Husband labor market (employed, or not) wife labor market, birth cohort husband and wife, country of birth of husband and wife, children under 16 years (except in the regression related to significant expenditure on children), population density, and region. $t$ statistics in parentheses.

$* \mathrm{p}<.05 .{ }^{* *} \mathrm{p}<.01 .{ }^{* * *} \mathrm{p}<.001$ 
Table 3. Multinomial Probit Regression (Mainly the wife compared to mainly the husband): Marginal Effects

\begin{tabular}{|c|c|c|c|c|c|}
\hline Explanatory variables & $\begin{array}{l}\text { Daily Household } \\
\text { Needs } \\
\text { Coeff. } \\
\text { (t-statistic) } \\
\end{array}$ & $\begin{array}{l}\text { Major Household } \\
\text { Purchases } \\
\text { Coeff. } \\
\text { (t-statistic) } \\
\end{array}$ & $\begin{array}{c}\text { Significant Expenditure } \\
\text { on Children } \\
\text { Coeff. } \\
\text { (t-statistic) }\end{array}$ & $\begin{array}{c}\text { Loans } \\
\text { Coeff. } \\
\text { (t-statistic) }\end{array}$ & $\begin{array}{c}\text { Savings } \\
\text { Coeff. } \\
\text { (t-statistic) }\end{array}$ \\
\hline Lower Secondary Education & $\begin{array}{c}-0.009 \\
(-0.768)\end{array}$ & $\begin{array}{c}-0.005 \\
(-0.632)\end{array}$ & $\begin{array}{c}-0.005 \\
(-0.305)\end{array}$ & $\begin{array}{c}-0.003 \\
(-0.616)\end{array}$ & $\begin{array}{c}-0.001 \\
(-0.111)\end{array}$ \\
\hline Upper Secondary Education & $\begin{array}{c}-0.050^{* * *} \\
(-3.811)\end{array}$ & $\begin{array}{l}-0.018^{*} \\
(-2.130)\end{array}$ & $\begin{array}{c}-0.030 \\
(-1.744)\end{array}$ & $\begin{array}{c}-0.013 * * \\
(-2.981)\end{array}$ & $\begin{array}{l}-0.013^{*} \\
(-2.472)\end{array}$ \\
\hline \multicolumn{6}{|c|}{ Wife education (Ref. Primary educ. or less) } \\
\hline Lower Secondary Education & $\begin{array}{c}0.023 \\
(1.872)\end{array}$ & $\begin{array}{l}0.017^{*} \\
(1.964)\end{array}$ & $\begin{array}{c}-0.008 \\
(-0.468)\end{array}$ & $\begin{array}{c}-0.002 \\
(-0.529)\end{array}$ & $\begin{array}{c}-0.002 \\
(-0.446)\end{array}$ \\
\hline Upper Secondary Education & $\begin{array}{c}0.014 \\
(1.064)\end{array}$ & $\begin{array}{c}0.006 \\
(0.691)\end{array}$ & $\begin{array}{l}-0.044^{*} \\
(-2.501)\end{array}$ & $\begin{array}{c}-0.001 \\
(-0.221)\end{array}$ & $\begin{array}{c}-0.010 \\
(-1.674)\end{array}$ \\
\hline Husband's wage & $\begin{array}{l}-1.3 \mathrm{e}-5^{*} \\
(-2.474)\end{array}$ & $\begin{array}{c}-1.5 \mathrm{e}-5^{* * *} * \\
(-3.728)\end{array}$ & $\begin{array}{c}-2.1 \mathrm{e}-5 * * * \\
(-3.455)\end{array}$ & $\begin{array}{c}-0.7 \mathrm{e}-6 * * * \\
(-3.325)\end{array}$ & $\begin{array}{c}-0.9 \mathrm{e}-6^{* * * *} \\
(-3.729)\end{array}$ \\
\hline Wife's wage & $\begin{array}{c}-7.2 \mathrm{e}-5 * * * \\
(-9.603)\end{array}$ & $\begin{array}{c}-0.6 e-6 \\
(-1.142)\end{array}$ & $\begin{array}{l}-0.1 \mathrm{e}-6 \\
(-0.158)\end{array}$ & $\begin{array}{c}0.4 \mathrm{e}-6 \\
(1.375)\end{array}$ & $\begin{array}{l}-0.1 \mathrm{e}-6 \\
(-1.208)\end{array}$ \\
\hline Control variables & Yes & Yes & Yes & Yes & Yes \\
\hline Log pseudo likelihood & -14004.2 & -9125.1 & -3725.6 & -6224.5 & -7017.9 \\
\hline$\chi^{2}$ & 1960.13 & 807.75 & 253.73 & 425.17 & 454.83 \\
\hline Degrees of freedom & 72 & 72 & 72 & 72 & 72 \\
\hline Probability $>\chi^{2}$ & 0.000 & 0.000 & 0.000 & 0.000 & 0.000 \\
\hline
\end{tabular}


Note: Control variables included are the following: Husband labor market (employed, or not) wife labor market, birth cohort husband and wife, country of birth husband and wife, children under 16 years (except in the regression related to significant expenditure on children), population density, and region. $t$ statistics in parentheses.

$* \mathrm{p}<.05 . * * \mathrm{p}<.01 . * * * \mathrm{p}<.001$ 
Appendix

Table A. Descriptive Statistics of independent variables

\begin{tabular}{|c|c|c|c|c|c|}
\hline Explanatory variables & $\begin{array}{l}\text { Daily } \\
\text { Household } \\
\text { Needs } \\
\text { (Percent) } \\
\end{array}$ & $\begin{array}{c}\text { Major } \\
\text { Household } \\
\text { Purchases } \\
\text { (Percent) } \\
\end{array}$ & $\begin{array}{c}\text { Significant } \\
\text { Expenditure } \\
\text { on Children } \\
\text { (Percent) } \\
\end{array}$ & $\begin{array}{c}\text { Loans } \\
\text { (Percent) }\end{array}$ & $\begin{array}{c}\text { Savings } \\
\text { (Percent) }\end{array}$ \\
\hline \multicolumn{6}{|l|}{ Husband education } \\
\hline Primary education or less & 34.14 & 33.55 & 16.60 & 32.35 & 33.43 \\
\hline Lower secondary education & 23.83 & 24.00 & 29.21 & 24.44 & 23.85 \\
\hline Upper secondary education & 18.03 & 18.17 & 23.28 & 18.44 & 18.13 \\
\hline Tertiary education & 24.00 & 24.29 & 30.91 & 24.77 & 24.59 \\
\hline \multicolumn{6}{|l|}{ Wife education } \\
\hline Primary education or less & 35.03 & 34.58 & 13.35 & 33.16 & 34.52 \\
\hline Lower secondary education & 23.75 & 23.78 & 27.40 & 24.13 & 23.70 \\
\hline Upper secondary education & 17.18 & 17.30 & 22.76 & 17.80 & 17.22 \\
\hline Tertiary education & 24.04 & 24.33 & 36.49 & 24.91 & 24.55 \\
\hline \multicolumn{6}{|l|}{ Husband labor market } \\
\hline Not employed & 43.41 & 42.84 & 18.55 & 40.70 & 42.93 \\
\hline Employed & 56.59 & 57.16 & 81.45 & 59.30 & 57.07 \\
\hline \multicolumn{6}{|l|}{ Wife labor market } \\
\hline Not employed & 57.96 & 57.54 & 41.15 & 56.13 & 57.58 \\
\hline Employed & 42.04 & 42.46 & 58.85 & 43.87 & 42.42 \\
\hline \multicolumn{6}{|l|}{ Wage (monthly in euros) } \\
\hline Husband's wage (mean) & 774.55 & 783.51 & $1,106.24$ & 812.80 & 786.67 \\
\hline Husband's wage (Std. Dev.) & $1,032.33$ & $1,036.17$ & $1,056.15$ & $1,041.70$ & $1,041.10$ \\
\hline Wife's wage (mean) & 484.34 & 489.90 & 699.76 & 507.28 & 491.76 \\
\hline Wife's wage (Std. Dev.) & 785.21 & 788.82 & 871.00 & 796.89 & 790.75 \\
\hline \multicolumn{6}{|l|}{ Birth cohort husband } \\
\hline 1959 or before & 56.31 & 56.10 & 15.19 & 54.45 & 56.41 \\
\hline 1960 to 1969 & 23.40 & 23.63 & 46.89 & 24.55 & 23.62 \\
\hline 1970 or after & 20.29 & 20.27 & 37.92 & 21.00 & 19.96 \\
\hline \multicolumn{6}{|l|}{ Birth cohort wife } \\
\hline 1959 or before & 49.74 & 49.45 & 7.29 & 47.67 & 49.81 \\
\hline 1960 to 1969 & 24.26 & 24.52 & 41.40 & 25.40 & 24.52 \\
\hline 1970 or after & 26.00 & 26.03 & 51.31 & 26.93 & 25.67 \\
\hline \multicolumn{6}{|l|}{ Country of birth of the husband } \\
\hline Born in Spain & 92.38 & 92.52 & 87.69 & 92.50 & 92.81 \\
\hline Not born in Spain & 7.62 & 7.48 & 12.31 & 7.50 & 7.19 \\
\hline \multicolumn{6}{|l|}{ Country of birth of the wife } \\
\hline Born in Spain & 91.08 & 91.24 & 85.94 & 91.26 & 91.69 \\
\hline Not born in Spain & 8.92 & 8.76 & 14.06 & 8.74 & 8.31 \\
\hline \multicolumn{6}{|l|}{ Children } \\
\hline Children under 16 years old & 62.98 & 62.64 & 100.00 & 61.28 & 62.95 \\
\hline Not children under 16 years old & 37.02 & 37.36 & 0.00 & 38.72 & 37.05 \\
\hline \multicolumn{6}{|l|}{ Population density } \\
\hline High density & 46.31 & 46.44 & 45.50 & 46.65 & 46.58 \\
\hline Middle density & 21.41 & 21.38 & 23.55 & 21.43 & 21.06 \\
\hline
\end{tabular}


32.28 32.18 30.95 31.93 32.36

\begin{tabular}{lrrrrr}
\hline \multicolumn{1}{c}{ Explanatory variables } & $\begin{array}{c}\text { Daily } \\
\text { (Percent) }\end{array}$ & $\begin{array}{c}\text { Purchases } \\
\text { (Percent) }\end{array}$ & $\begin{array}{c}\text { Child } \\
\text { (Percent) }\end{array}$ & $\begin{array}{c}\text { Loans } \\
\text { (Percent) }\end{array}$ & $\begin{array}{c}\text { Saving } \\
\text { (Percent) }\end{array}$ \\
\hline Regions & & & & & \\
\hline Andalusia & 11.77 & 11.81 & 13.49 & 12.16 & 12.01 \\
Aragon & 4.40 & 4.43 & 4.22 & 4.52 & 4.42 \\
Asturias & 4.56 & 4.56 & 3.36 & 4.49 & 4.48 \\
Balearic Islands & 3.19 & 3.18 & 3.33 & 3.36 & 3.20 \\
Basque Country & 5.09 & 5.14 & 5.10 & 5.33 & 5.18 \\
Canary Islands & 4.16 & 4.18 & 4.95 & 4.25 & 4.15 \\
Cantabria & 3.15 & 3.17 & 2.92 & 3.04 & 3.06 \\
Castile and Leon & 6.71 & 6.72 & 5.79 & 6.78 & 6.84 \\
Castile-La Mancha & 5.43 & 5.38 & 6.11 & 5.17 & 5.42 \\
Catalonia & 10.72 & 10.70 & 10.74 & 10.83 & 10.90 \\
Extremadura & 4.08 & 4.11 & 3.67 & 4.16 & 4.22 \\
Galicia & 7.95 & 7.87 & 6.04 & 7.69 & 7.93 \\
Madrid (Region of) & 8.84 & 8.84 & 8.86 & 8.76 & 8.83 \\
Murcia & 3.98 & 3.97 & 4.75 & 3.96 & 3.69 \\
Navarre & 3.38 & 3.39 & 3.64 & 3.34 & 3.22 \\
Rioja (La) & 3.35 & 3.31 & 2.91 & 3.23 & 3.41 \\
Valencian Community & 7.46 & 7.50 & 7.58 & 7.19 & 7.25 \\
Autonomous cities (Ceuta-Melilla) & 1.78 & 1.74 & 2.54 & 1.75 & 1.80 \\
\hline$N$ & 18,387 & 18,118 & 6,807 & 16,914 & 17,432 \\
\hline$N$ Note: Figures are in percentages, except wages, which are in euros. & & &
\end{tabular}

